INTERNATIONAL JOURNAL OF RESEARCHES IN BIOSCIENCES, AGRICULTURE \& TECHNOLOGY (C) VISHWASHANTI MULTIPURPOSE SOCIETY (Global Peace Multipurpose Society) R. No.MH-659/13(N) www.vmsindia.org

\title{
DETERMINATION OF INTRINSIC STRESS DUE TO LEAD SELENIDE THIN FILMS USING DOUBLE EXPOSURE HOLOGRAPHIC INTERFEROMETRY
}

${ }^{1}$ Mane R.D., ${ }^{1}$ Chikode P.P. and ${ }^{2}$ Dongare M.B.

\author{
1Jaysingpur College, Jaysingpur (M.S.) India \\ ${ }^{2}$ Shivaji University, Kolhapur (M.S.) India \\ Email:drmanerd@gmail.com
}

\begin{abstract}
The paper describes the application of double exposure holographic interferometry (DEHI) to determine the intrinsic stress developed on the substrate by using D.C. electrodeposition technique.The effect on the structural and optical properties of lead selenide thin films deposited on stainless steel and FTO coated glass substrates have been discussed.The electrodeposition of lead chalcogenides thin films was systematically carried out to understand electrochemical reactions and to optimize deposition conditions to achieve high quality lead chalcogenide thin films. The double exposure holograms were recorded for PbSe deposited thin films, varying the different exposure times from 10 to 40 sec. The interference fringes localized on the surface go on increasing as the time increases and the film thickness also increases. Using these interference fringes intrinsic stress is determined.
\end{abstract}

Keywords:Double exposure, Holographic interferometry, Electrodeposition

\section{Introduction:}

Lead chalcogenides are IV-VI compound semiconductor with a narrow band gap used in photo detectors, photoresistors and photoemitters in infrared. Lead chalcogenides are special structure, morphology and grain size; which have semiconductor nanocrystals having many unique properties, such as electrical, optical and magnetic [1-5]. Lead chalcogenides have attracted considerable attention because of their interesting properties and wide use as thermoelectric cooling materials, optical fibers, optical recording materials, solar cells, superionic materials, sensor and laser materials [6-9]. This has wide variety of applications in IR detectors, photographic plates and photovoltaic absorbers [10]. Lead chalcogenides deposition can be done by various methods but compared to these methods, electrodeposition is a simple, cost-effective and fast deposition technique which also allows precise control of composition, crystallographic structure; texture and grain size [11-15]. Strel'tsov et al. have investigated the cathodicelectro deposition of lead chalcogenides [16, 17]. The potential and current controls have been used but in general more stoichiometric, adhesive and dense films have been produced potentiostatically. XRD detects crystalline phases of the film. In the aqueous solutions the depositions are normally carried out at room temperature [18-22]. $\mathrm{PbSe}$ are narrow band gap semiconductors. Their crystal structure is face centered cubic, the coordination in the structure is six and the bond between $\mathrm{Pb}$ and $\mathrm{Se}$ to be ionic. The minimum energy gap (Eg) between the conduction band and the valence band is direct. The PbSe have many special characteristics in comparison with other semiconductors [23].

In this paper, effect on the structural and optical properties of lead selenide thin films deposited on stainless steel and FTO coated glass substrates have been discussed. The electrode position of $\mathrm{PbSe}$ thin films was systematically carried out to understand electrochemical reactions and to optimize deposition conditions to achieve high quality $\mathrm{PbSe}$ thin films. We have taken lead acetate solution as a precursor solution and sodium thiosulphate, selenous acid, sodium telluride solutions which are mixed with lead acetate with EDTA sequentially to form the $\mathrm{PbSe}$ thin films. The electrode position technique has been used for the deposition of $\mathrm{PbSe}$ In the present work, we have utilized the double exposure holographic interferometry (DEHI) technique for the study of surface deformation of stainless steel substrate, after completion of the deposition of $\mathrm{PbSe}$ films onto it. We have calculated the stress developed due to the 
deposition of film. Also, evaluated the rate of mass deposition for different deposition times and determined the thickness of thin film. For the deposition of thin films, we have adopted d.c. electrode position technique.

\section{Experimental:}

Electrode position of Lead Selenide Thin Films

The Lead acetate powder was dissolved in appropriate quantity of double distilled water to obtain desired solution of the $0.1 \mathrm{M}$ concentration. Similarly selenious acid powder ( $\mathrm{SeO} 2)$ was dissolved in appropriate quantity of double distilled water to obtain desired solution of the $0.1 \mathrm{M}$ concentration. In the electrolyte bath, the electrode position process occurs in the solution and it results into the formation of selenide thin film on the stainless steel substrate.

\section{Polarization studies}

The deposition potentials are obtained for the deposition of the lead, selenide and lead selenide thin films by using a conventional three-electrode cell. A saturated calomel electrode was used as a reference electrode and graphite as a counter electrode. The deposition was carried out from unstirred bath under potentiostatic mode onto stainless steel and FTO coated glass substrates. In order to determine deposition potential, the cathodic polarization curves were obtained for $0.1 \mathrm{M} \mathrm{Pb}\left(\mathrm{CH}_{3} \mathrm{COO}\right)_{2}, 0.1$ $\mathrm{M} \mathrm{SeO}_{2}$ and $0.1 \mathrm{M}$ EDTA using stainless steel substrates as shown in Fig. 1 (a), also using FTO coated glass substrates as shown in Fig. 1 (b).

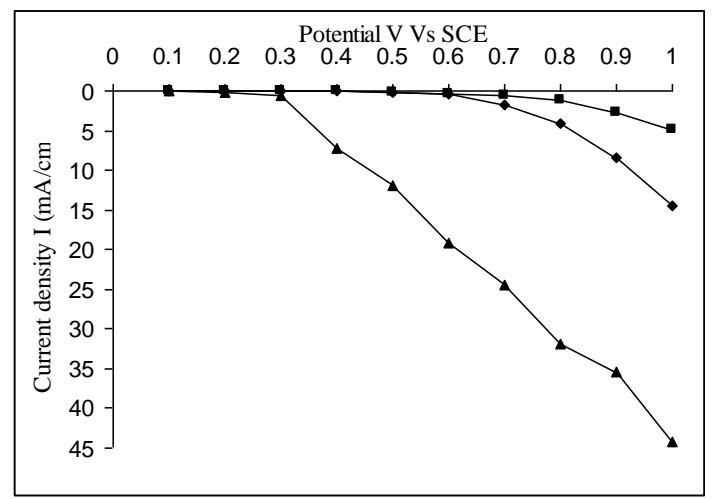

Fig. 1 (a) Polarization curve for $\mathrm{Pb}, \mathrm{Se}, \mathrm{PbSe}$ thin film deposited on stainless steel substrate.

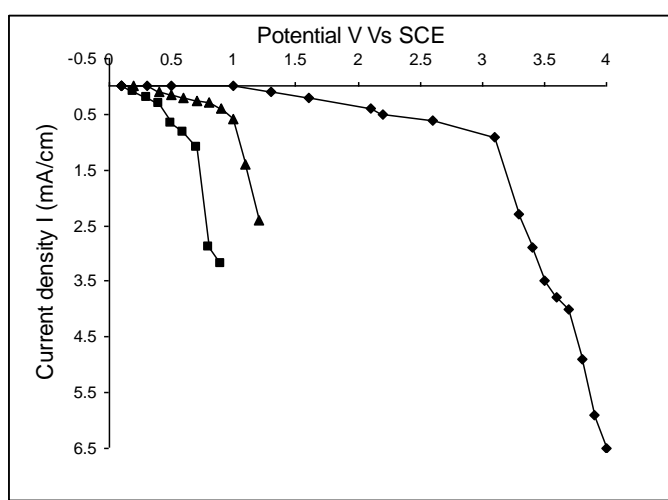

Fig. 2 (b) Polarization curve for $\mathrm{Pb}, \mathrm{Se}, \mathrm{PbSe}$ thin film deposited on FTO coated glass substrate.

\section{Formation PbSe thin film}

The selenium oxide was dissolved in double distilled water to obtain selenous acid of the $0.1 \mathrm{M}$ concentration, according to chemical reaction,

$$
\mathrm{SeO}_{2}+\mathrm{H}_{2} \mathrm{O} \longrightarrow \mathrm{H}_{2} \mathrm{SeO}_{3}
$$

In the present case the two components of co-deposition mechanisms are the precursors of selenium and lead to form lead selenide. For selenium following reactions commonly occur,

$\mathrm{H}_{2} \mathrm{SeO}_{3}+6 \mathrm{H}++6 \mathrm{e}-\stackrel{\mathrm{H}_{2} \mathrm{Se}}{\longrightarrow}$ (aq.) $+3 \mathrm{H}_{2} \mathrm{O}$ (1)

$\mathrm{H}_{2} \mathrm{SeO}_{3}+2 \mathrm{H}_{2} \mathrm{Se} \leftrightarrows 3 \mathrm{Se}+2 \mathrm{H}_{2} \mathrm{O}(2)$

Reaction (1) in co-deposition process is important as 6e- reduction of $\mathrm{Se} 4+$ ions to $\mathrm{Se} 2$ - ions. As $\mathrm{H} 2 \mathrm{SeO} 3$ is soluble compound, it may react with the selenous acid to obtain excess selenium following reaction (2).

\section{E H I Technique}

The stainless steel substrate immersed in a solution for electrode position, is used as an object. Initially, the single hologram is recorded with exposure time of five seconds on holographic plate without any deposition. The reduction potential is applied across the electrodes due to which thin film of $\mathrm{PbSe}$ was deposited on to the substrate and then the second exposure of 5 second was given on same photographic plate. The holographic plate was processed (Kodak $8 \mathrm{E}$ $75 \mathrm{HD}$ ) and replaced in reference wave path. The reconstructed image of substrate was observed which showed the fringes that are localized on its surface where the film is deposited. We have prepared the solutions 
of different concentrations and deposition time was varied from $10 \mathrm{sec}$. to $40 \mathrm{sec}$. The holograms were recorded by conventional two beam off-axis technique [24-26] which are shown in Fig. 2. For the deposition of lead selenide thin films onto the steel substrate, we prepared solutions with three different molarities of $\left[\mathrm{Pb}\left(\mathrm{CH}_{3} \mathrm{COO}\right)_{2}+\right.$ $\mathrm{SeO}_{2}+$ EDTA ] for 0.05M, 0.1 M and 0.15M.

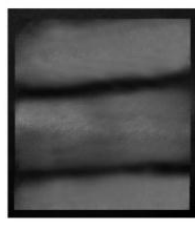

(a)

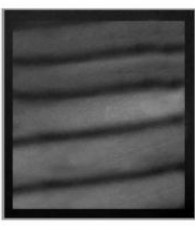

(c)

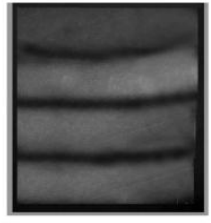

(b)

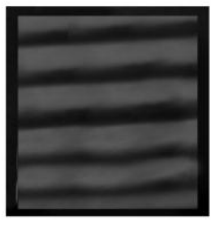

(d)
Fig-2: Photographs of Interferograms of PbSe Thin Films For $0.05 \mathrm{M}$

(a) $10 \mathrm{sec}$.

(b) 20 sec. (c) 30 sec. (d) 40 sec.

\section{Results and Discussion: \\ Bath Composition}

$\mathrm{PbSe}$ thin films were cathodically electrodeposited from aqueous solution containing different concentrations on stainless steel substrate, where EDTA was used as a complexing agent in the bath in order to control the rate of reaction. The different preperative parameters of the deposition were studied and optimized. All deposition was carried out in an unstirred condition and at room temperature.

\section{$X$-ray diffraction studies}

The structural identification of $\mathrm{PbSe}$ thin film was carried out by using $X$ - ray diffraction in the range of diffraction angle $2 \theta$ between $10^{\circ}$ and $100^{\circ}$. It was found from XRD pattern, that the films were claubsthalite cubic structure with preferred orientation along (202) plane. The d-values of XRD reflection were compared with standard d-values taken from Joint Committee on Powder Diffraction on Standards (JCPDS) data [27] and are presented in Table No. 1. The XRD pattern of the lead selenide thin film from the aqueous bath at room temperature on stainless steel substrate is also shown in Fig. 3. The film is polycrystalline with orientation along $\left(\begin{array}{lll}2 & 0 & 2\end{array}\right),\left(\begin{array}{lll}3 & 0 & 0\end{array}\right),\left(\begin{array}{lll}3 & 0 & 2\end{array}\right)$ planes.

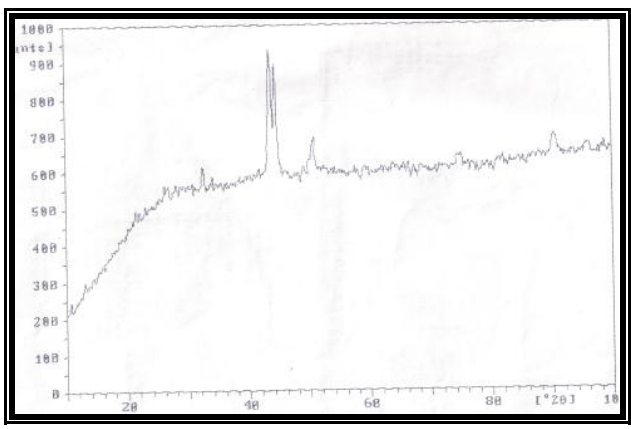

Fig.-3. The XRD pattern of the PbSe thin film on stainless steel substrate.

Table No. 1The inter planer distance compared with standard d values for $\mathrm{PbSe}$ thin film.

\begin{tabular}{|c|c|c|c|c|c|c|}
\hline $\begin{array}{c}\text { Sr.No } \\
\cdot\end{array}$ & $\begin{array}{c}\text { Angle } \\
2 \theta^{0}\end{array}$ & $\begin{array}{c}\text { Observe } \\
\mathrm{d} \mathrm{d} \\
\text { values } \\
\mathrm{A}^{0}\end{array}$ & $\begin{array}{c}\text { Standar } \\
\mathrm{d} \mathrm{d} \\
\text { values } \\
\mathrm{A}^{0}\end{array}$ & $\begin{array}{c}\text { Plan } \\
\mathrm{e} \\
\mathrm{h} \mathrm{k} 1\end{array}$ & $\begin{array}{c}\text { Compositi } \\
\text { on }\end{array}$ & $\begin{array}{c}\text { Structu } \\
\text { re }\end{array}$ \\
\hline 1 & $\begin{array}{c}43.54 \\
5\end{array}$ & 2.0767 & 2.006 & $\begin{array}{c}(202 \\
)\end{array}$ & PbSe & Cubic \\
\hline 2 & $\begin{array}{c}50.70 \\
0\end{array}$ & 1.7991 & 1.774 & $\begin{array}{c}(300 \\
)\end{array}$ & PbSe & Cubic \\
\hline 3 & $\begin{array}{c}74.82 \\
5\end{array}$ & 1.2678 & 1.288 & $\begin{array}{c}(302 \\
)\end{array}$ & PbSe & Cubic \\
\hline
\end{tabular}

\section{Measurements of grain size}

The film morphology and crystallographic structure were investigated by scanning electron microscope (SEM) (JOEL - JSM 6360 Japan) is shown in fig.4. The images show the detailed microstructure of the films. The average grain size of $\mathrm{PbSe}$ is almost uniform and dense, has a value in between 1 and $10 \mu \mathrm{m}$.

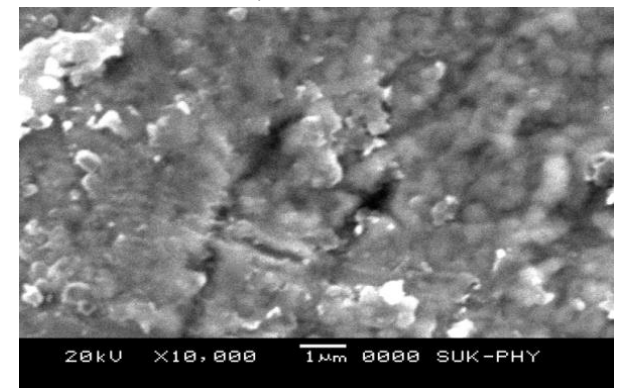

Fig.4. SEM image for PbSe thin films of $\mathrm{X} 10000$. 


\section{Determination of Intrinsic Stress}

The use of DEHI technique is a simple nondestructive method for the quantitative measurement of stress in thin film. The intrinsic stress inside the film measured by the following

Equation no. 1 and 2[28, 29],

$$
S=\frac{T_{s}{ }^{2} Y_{S} \delta}{3 l^{2} T_{f}}
$$

Where, $\mathrm{S}=$ Stress in dyne $/ \mathrm{cm}^{2}, \mathrm{~T}_{\mathrm{s}}=$ Thickness of substrate, $Y_{s}=$ Young modulus of substrate,

$1=$ length of substrate, $\mathrm{T}_{\mathrm{f}}=$ thickness of thin film, $\delta=$ deflection of substrate.

$$
\delta=\frac{n \lambda}{\cos \theta_{i}+\cos \theta_{s}}
$$

If $\theta_{\mathrm{i}}$ and $\theta_{\mathrm{s}}$ are small then $\delta=\frac{n \lambda}{2} \quad$ where, $\mathrm{n}$ $=$ total number of fringes, $\lambda=$ wavelength of laser light and $T_{f}=\frac{m}{\rho A}$

Where, $\mathrm{T}_{\mathrm{f}}=$ film thickness, $\mathrm{m}=$ mass of the film deposited on area A of the substrate, $\rho=$ density of the material in the bulk form.

After recording of hologram, the reconstructed image has superimposed fringe pattern corresponding to a deflection of substrate measured. In DEHI method, stress measurement has been performed in situ during the electrochemical reaction of palladium hydride formation with anodic oxidation. The estimated value of stress and deflection of substrate as reported in Table No. 2

Table No.2 Observed Data for PbSe Thin Films

I] For 0.05M of solution $\left[\mathrm{Pb}\left(\mathrm{CH}_{3} \mathrm{COO}\right)_{2}+\right.$ $\mathrm{SeO}_{2}+$ EDTA ]

\begin{tabular}{|c|c|c|c|c|c|}
\hline $\begin{array}{c}\text { Time of } \\
\text { depositi } \\
\text { on t sec. }\end{array}$ & $\begin{array}{c}\text { No. } \\
\text { of } \\
\text { fring } \\
\text { es } \\
\mathrm{n}\end{array}$ & $\begin{array}{c}\text { Thickne } \\
\text { ss of } \\
\text { thin } \\
\text { film } \\
\mathrm{T}_{\mathrm{f}}(\mu \mathrm{m})\end{array}$ & $\begin{array}{c}\text { Mass of } \\
\text { PbSe } \\
\text { deposit } \\
\text { ed }(\mathrm{mg})\end{array}$ & $\begin{array}{c}\text { Deflecti } \\
\text { on of } \\
\text { substra } \\
\text { te } \\
\delta(\mu \mathrm{m})\end{array}$ & $\begin{array}{c}\text { Calculate } \\
\mathrm{d} \text { stress } \\
\mathrm{S} \times 10^{9} \\
(\mathrm{dynes} / \mathrm{c} \\
\left.\mathrm{m}^{2}\right)\end{array}$ \\
\hline 10 & 2 & 28.83 & 0.94 & 0.6328 & 0.5853 \\
\hline 20 & 3 & 39.87 & 1.3 & 0.9492 & 0.5348 \\
\hline 30 & 4 & 60.73 & 1.98 & 1.2656 & 0.5557 \\
\hline 40 & 5 & 62.27 & 2.03 & 1.5820 & 0.4775 \\
\hline
\end{tabular}

II] For $0.1 \mathrm{M}$ of solution $\left[\mathrm{Pb}\left(\mathrm{CH}_{3} \mathrm{COO}\right)_{2}+\right.$ $\mathrm{SeO}_{2}+$ EDTA ]

\begin{tabular}{|c|c|c|c|c|c|}
\hline $\begin{array}{c}\text { Time of } \\
\text { deposition } \\
\mathrm{t} \text { sec. }\end{array}$ & $\begin{array}{c}\text { No. of } \\
\text { fringes } \\
\mathrm{n}\end{array}$ & $\begin{array}{c}\text { Thickness } \\
\text { of thin film } \\
\mathrm{T}_{\mathrm{f}}(\mu \mathrm{m})\end{array}$ & $\begin{array}{c}\text { Mass of } \\
\text { PbSedeposited } \\
(\mathrm{mg})\end{array}$ & $\begin{array}{c}\text { Deflection } \\
\text { of } \\
\text { substrate } \\
\delta(\mu \mathrm{m})\end{array}$ & $\begin{array}{c}\text { Calculated } \\
\text { stress } \\
\mathrm{S} \mathrm{x} \mathrm{10^{9 }} \\
\left(\mathrm{dynes} / \mathrm{cm}^{2}\right)\end{array}$ \\
\hline 10 & 3 & 33.74 & 1.1 & 0.9492 & 0.7502 \\
\hline 20 & 5 & 55.21 & 1.8 & 1.5820 & 0.7441 \\
\hline 30 & 7 & 76.68 & 2.5 & 2.2148 & 0.7302 \\
\hline 40 & 9 & 98.16 & 3.2 & 2.8476 & 0.7235 \\
\hline
\end{tabular}

III] For $0.15 \mathrm{M}$ of solution $\left[\mathrm{Pb}\left(\mathrm{CH}_{3} \mathrm{COO}\right)_{2}+\right.$ $\mathrm{SeO}_{2}+$ EDTA ]

\begin{tabular}{|c|c|c|c|c|c|}
\hline $\begin{array}{c}\text { Time of } \\
\text { deposition } \\
\mathrm{t} \text { sec. }\end{array}$ & $\begin{array}{c}\text { No. of } \\
\text { fringes } \\
\mathrm{n}\end{array}$ & $\begin{array}{c}\text { Thickness } \\
\text { of thin film } \\
\mathrm{T}_{\mathrm{f}}(\mu \mathrm{m})\end{array}$ & $\begin{array}{c}\text { Mass of } \\
\text { PbSe } \\
\text { deposited } \\
(\mathrm{mg})\end{array}$ & $\begin{array}{c}\text { Deflection } \\
\text { of } \\
\text { substrate } \\
\delta(\mu \mathrm{m})\end{array}$ & $\begin{array}{c}\text { Calculated } \\
\text { stress } \\
\mathrm{S} \times 10^{9} \\
\left(\mathrm{dynes} / \mathrm{cm}^{2}\right)\end{array}$ \\
\hline 10 & 4 & 40.184 & 1.31 & 1.2656 & 0.8398 \\
\hline 20 & 6 & 69.325 & 2.26 & 1.8984 & 0.7302 \\
\hline 30 & 8 & 115.951 & 3.78 & 2.5312 & 0.5821 \\
\hline 40 & 9 & 157.668 & 5.14 & 2.8476 & 0.4816 \\
\hline
\end{tabular}

\section{Conclusions:}

We have employed the DEHI technique, to measure the deflection of substrate and to calculate the stress due to deposition. It gives better information regarding the deflection of substrate. This technique is useful and easy for the determination of stress parameter in thin films. In order to determine the deflection of the substrate i.e. deformation of the substrate, the relevant number of fringes can be measured directly from the hologram for the further use.

\section{Acknowledgement:}

The authors are thankful to UGC, New Delhi for financial assistance under the scheme of minor research project during XIIth plan.

\section{References:}

C.C. Chen, A.B. Herhold, C.S.Johnson, A.P.Aliviscios science 276(1997), p.398. M.G.Bawendi, M.L. Steigerwald, L.E. Brus, Annu, Rev Phys. Chem.41 (1990), p.477.

Motte, F. Billoudet, F.Laxaxe, J. Douin, M.P.J. Meni. Phys. Chem.B.101 (1997), p.138.

J. Yang, F.C.Meldrum, JIIJ. Fendier, Phys. Chem. 99(1995), p.5500.

N. Herron, Y. Wang, H. Echert, J.Am. Chem. Soc.112 (1990), p.1322.

F. Mongollaz, A. Fillot, R. Griot, L. J. Do. Lalloc, Proc. SPIE- Int. Soc. Opt. Eng 156 (1994), p.2227.

W.Z. Wang, Y. Geng, P. Yan, F.Y. Liu, Y. Xie, Y. T. Oian, J.Am.Chem. Soc. 121 (1999), p.4062.

S.T. Lakshmikumar, A.C. Rastogi, Sol. Energy Mater. Sol. Energy Mater.Sol. Cell. 32(1994),

p.7.

M.A. Korzhuev, Fiz. Khim. Obrab. Mater.3 (1991), p.131.

R.N. Mulik, C.B.Rotti, B.M.More, D.S. Sutrave, G.S Shahane K.M.Garadkar, I.P .Deshmukh, R.R. Hankare, Indian J. Pure Appl. Phys,34(1996), p.903.

De Tacconi N.R, Medvedko, O. and Rajeshwar K. J. Electroanal. Chem; 379 (1994), p. 545. 
De Tacconi, N.R.and Rajeshwar K. J. Electroanal. Chem., 444 (1998), p.7.

Ponomarev E.A.,Albu-Yaron A.,Tenne R. and Leavy-Clement

C.,J.Electrochem.Soc.144(1997),p.L277.

Ponomarev E.A., Neumann-Spallart M.,Hodes G. and Leavy-Clement C., Thin Solid Films,280(1996),p.86.

Albu-Yaron A., Levy-Clement C. and Hutchison J.L., Electrochem. Solid State. Lett.2 (1999), p.627.

Strel'tsov

E.A.,Osipovich

N.P.,Ivashkevich L.S.,Lyakhov A.S. and Sviridov V.V.,Russ.

J.Appl.Chem.70(1997),p.1651.

Stre'tsov E.A., Osipovich N.P., Ivashkevich L.S.,Lyakhov A.S. and Sviridov V.V., Electrochim. Acta.(1997), p.869.

Saksena S.,Pandya D.K. and Chopra K.L.Thin Solid Films ,94(1982), p. 223.

Neumann-Spallart $M$. and Koningstein, $\mathbf{C}$. Thin Solid Films, 265(1995), p.33.

Konigstein C. and Neummann-Spallart $M$. J.Electrochem. Soc.145(1998), p.337.

Samantilleke A.P. ,Boyle M.H.,Young J. and Dharmadasa I. M.,J.Mat. Sci.Mat. Electron. 9(1998) , p. 289.
BozziniB ., Baker M. A. , cavallotti P.L., Cerri E and Lenardi C. Thin Solid Films, 361 -

362(2000), p.388.

Kothiyal, G.P. and B. ProgCrystGrowth charact. 20(1990), p. 313.

Leith E.N. and Upatnieks J.J. opt Soc. Amer 5 (1962),p. 1123.

Leith E.N. and Upatnieks J.J. opt Soc. Amer 53 (1963),p. 1377.

Leith E.N. and Upatnieks J.J. opt Soc. Amer 54 (1964),p. 1295. JCPDS data file No.6-354.

T.S.Radha, Ph.D. Thesis. IISc Bangalore (1993)

A G Read, J P.G. Farr \& K.G. Sheppard, Sur, Tech. 8 (1979)p.325 